\title{
Quality Assurance Framework in Technical and Vocational Education and Training: A Comparative Study of Nigeria, Malaysia and UK
}

\author{
Wafudu Satumari Johnn ${ }^{1, *}$, Kamin Bin Yusri ${ }^{2}$ \\ ${ }^{1}$ College of Education, Hong, Adamawa State, 2237, Yola, Nigeria \\ ${ }^{2}$ Faculty of Social Sciences and Humanities, Universiti Teknologi Malaysia, Johor, Malaysia
}

Received April 20, 2021; Revised June 15, 2021; Accepted July 19, 2021

\section{Cite This Paper in the following Citation Styles}

(a): [1] Wafudu Satumari John, Kamin Bin Yusri , "Quality Assurance Framework in Technical and Vocational Education and Training: A Comparative Study of Nigeria, Malaysia and UK," Universal Journal of Educational Research, Vol. 9, No. 8, pp. 1531 - 1543, 2021. DOI: 10.13189/ujer.2021.090805.

(b): Wafudu Satumari John, Kamin Bin Yusri (2021). Quality Assurance Framework in Technical and Vocational Education and Training: A Comparative Study of Nigeria, Malaysia and UK. Universal Journal of Educational Research, 9(8), 1531 - 1543. DOI: 10.13189/ujer.2021.090805.

Copyright@2021 by authors, all rights reserved. Authors agree that this article remains permanently open access under the terms of the Creative Commons Attribution License 4.0 International License

\begin{abstract}
This study aims to compare the technical vocational education and training quality assurance framework of Nigeria, Malaysia and the United Kingdom. The study adopted a qualitative method document analysis to elicit information to compare quality assurance frameworks of Nigeria, Malaysia and the United Kingdom in the context of the technical vocational education and training systems. The study revealed current practices of quality assurance frameworks of Nigeria, Malaysia and the United Kingdom. The framework's emphasis on appropriately skilled workforce needed for socio-economic development and sets a benchmark for consistency to promote trust. The study also revealed similarities as a commitment to evidence-based decision making for continuous quality improvement while the difference in quality assurance frameworks of Nigeria and Malaysia is revealed based on the government-led approach and the United Kingdom operates based on a unitary approach. The study also revealed suitable quality assurance framework components as follows: integrated planning, integrated reviewing and management. This study discussed reforms needed of quality assurance framework in technical vocational education and training system and suggested that Nigerian government needed to encourage her technical vocational education and training system for the desired objectives through quality assurance framework.
\end{abstract}

Keywords Quality Assurance, Framework, Technical
Vocational Education and Training

\section{Introduction}

Quality assurance QA is a component of quality management that provides confidence for the stakeholders to meet the quality desires of the educational services. QA simply refers to planned and systematic processes that provide confidence in technical vocational education and training TVET services by the providers. It is an established activity provided by QA bodies and agencies to ensure satisfaction in yielding high-quality products to build trust in customers [1]. The four key processes that form the basis of QA are known as the PDCA cycle or Deming cycle, which include:

i. The planning stage of the PDCA cycle needs to be operationalized based on the best indications, such as who will do it, what the activities are, with whom and under what conditions. TVET institutions must have an organized process supported by the required resources to achieve high-quality end products endorsed with appropriate knowledge, skills and competency.

ii. The do stage of the PDCA cycle offers an opportunity to identify how the plan is 
implemented and what must be in place to achieve the desired TVET objectives? Hence, the provider's approved materials are required to be used by the teachers to deliver the TVET objectives.

iii. The check stage of the PDCA cycle supervises and assesses the TVET products to determine whether the TVET products meet the targeted objectives. The learning outcomes of the TVET products are compared to the objectives and a decision will be made whether the objectives are achieved or not.

iv. The PDCA cycle's action stage examines the TVET system to implement actions necessary to achieve TVET improvement and ensure quality within the TVET system.[1; 2; 3]. Thus, the Deming quality cycle's main objective is to assist in planning to carry on a process, to do it, verify or check it to make sure that standards and quality requirements are met. Therefore, QA is a collection of policies, procedures, systems, and practices designed to achieve, maintain and enhance the quality of the TVET system. As such, quality assurance requires heavy investment to acquire the best technology, skills and competencies for national development $[4 ; 3]$.

More so, [4] defined the Quality assurance framework QAF as a link to QA processes that set standards to achieve coherence and trust within the national educational system. The quality assurance framework outlines principles for QA in the TVET system which includes:

i. Assessment, evaluation and review of TVET systems about quality criteria and indicators.

ii. Monitor processes which comprise of internal and external QA mechanisms to identify weakness and strength of TVET system and areas of improvement.

iii. Ensure measures to provide TVET effectiveness [5; 4].

Thus, QAF is an instrument that promotes and monitors the improvement of the TVET systems and measures the benchmark to improve the quality of TVET systems implemented or need to be reviewed. Hence, the TVET framework aims at continuous improvement in technological development [6; 7].

TVET is a practical-oriented program to acquire employable skills in the world of work, and most developing nations, particularly Nigeria, need a skilled workforce to transform their economic drive through the available natural resources [8; 9]. As such, a well-quality TVET system is suitable to train the skilled workforce needed by developing nations, especially Africans, in particular Nigeria, to address its socio-economic development challenges [10]. In another way, [4] and [11] opine that TVET is a systematic application of scientific knowledge to practical tasks towards effective control of natural resources, aimed at self-reliance, sustainability and steady, progressive national development. It thrives on technical knowledge but is cultivated through the practice of basic skills. TVET is an aspect of education that allows the recipients to acquire practical skills as well as basic scientific knowledge that will fit the individuals for gainful employment in recognized occupations as semi-skilled or technicians [12]. Therefore, TVET provides individuals with the skills, knowledge and attitudes required for the world of work. However, the demand for technical vocational education and training (TVET) has increased in recent decades with the rapid technological changes in industries and labor market demands. As a result, quality assurance roles in TVET systems are essential because they aid in the development of workers' knowledge, skills, and competencies in the face of technological changes. Thus, quality assurance is a priority in TVET systems, because it prevents challenges to meeting labour market demands $[1 ; 4 ; 3]$. However, the quality assurance framework in the TVET facilitates the quality of skills, knowledge and competency of products for socio-economic development $[1 ; 4]$. With this, the TVET quality assurance frameworks have become a central issue accorded priority for new technologies worldwide and, to achieve it, quality has to be assured. More so, understanding of quality and the possible ways and means of assuring a quality framework in the TVET systems varies from country to country. Quality assurance in TVET is meeting and conforming to generally accepted standards as defined by quality assurance bodies or by professional committees [3; 10]. Therefore, assuring a quality framework for TVET has become a task because it has to comply with the current labour market demands. [13], quality frameworks in TVET systems are a focus of all stakeholders in today's fast-challenging technological development to reflect innovative approaches, creative approaches, and output-based policies for quality standards [14]. To fulfil the vision and mission of quality frameworks in TVET, the providers have to set up different procedures and methods to implement innovative policies and strategies to strengthen and assure TVET programs at all levels [14]. It could go a long way to improving and strengthening human capacities through equipping the TVET graduates with the skills, knowledge, and competency, the spirit of professional excellence, honesty, good ethics and morality. Hence, QAF was established to provide quality standards to form the basis for quality performance and institutional excellence by guiding training, and employees' need for up-skilling to address employers' needs. However, the quality assurance framework in TVET in various countries around the world, particularly in Africa and particularly in Nigeria, is facing challenges with quality and effective policies for skill development to ensure socioeconomic development [15, 16]. Furthermore, there are issues with insufficient funding in the TVET system. [7] And [10], affirmed that 
government funding of the TVET system has been inadequate because education's share of gross domestic product GDP is quite low. And many countries, especially African nations, in particular Nigeria, have yet to meet the UNESCO recommendation of a minimum of 26 per cent of the budgetary allocation to education [17]. Thus, TVET, like any other sector of the educational system, requires financial support to ensure quality. However, due to insufficient funding, most TVET frameworks are unable to produce a professional skilled workforce for socio-economic development [18]. Therefore, this study intends to be a comparative study to reveal a functional quality assurance framework in TVET systems for skills development which could be emulated by other countries [19]. In addition, the study will help TVET stakeholders develop an effective, relevant, and equitable quality assurance framework for their country's context, and to that end, the study will compare the quality frameworks of TVET systems in Nigeria, Malaysia, and the United Kingdom. Above that, to ensure quality standards in TVET institutions (formal or informal), we do have in place QA mechanisms that are suitable for their socio-economic and educational aspirations. For example, Nigeria employed multi QA systems to supervise and enforce quality assurance of her educational institutions. The QA agencies developed the minimum academic standards MAS as a benchmark for QA and have set standards following the quality assurance framework guidelines for their institutional operations [20]. The agencies focus on accreditation strategies and emphasis on quality improvement, compliance and seek to achieve accountability for quality performance. The agencies include the National Universities Commission NUC, responsible for supervising and regulating quality assurance of the universities, the National Board for Technical Education NBTE, responsible for regulating polytechnics, mono-technics, technical colleges and Vocational Enterprise Institutions $\mathrm{VEI}_{\mathrm{s}}$, and the National Commission for Colleges of Education NCCE, which supervises and regulates all colleges of education [21; 22; 23]. The three agencies are responsible for quality assurance through minimum accreditation requirements, among others, such as library space, minimum staff/students' ratio, minimum facilities/equipment and offices for staff, and effective teaching and learning in given occupations $[21 ; 24 ; 25]$. This is to ensure that quality standards are regulated, maintained and enhanced by the TVET institutions in line with the needs of societies as well as industries. However, the national vocational qualification framework, NVQF, was established under the regulations of the NBTE to monitor and evaluate the TVET QA. NVQF provides quality standards, transparency, access, accountability, and comparability of training to labor market demands. The NVQF has six levels, as shown in Table 1 [26].

In line with the National Skills Qualifications NSQ,
National Occupational Standards NOS were developed in occupational areas to measure the performance outcomes of individual recipients in a place of work in a given occupation [26;9].

Table 1. Level of National Technological Skills Qualifications

\begin{tabular}{|c|c|}
\hline $\begin{array}{c}\text { Level of } \\
\text { national skills } \\
\text { qualification }\end{array}$ & Description of technological skills \\
\hline NVQF 1 & Unskilled employees: labor trade certificate 3 \\
\hline NVQF 2 & Basic skilled employees: labor trade certificate 2 \\
\hline NVQF 3 & $\begin{array}{c}\text { Semi-skilled employees: national technical } \\
\text { certificate NTC, national business certificate } \\
\text { NBC, labor trade certificate 1 }\end{array}$ \\
\hline NVQF 4 & $\begin{array}{c}\text { Technicians, skilled employees: national } \\
\text { diploma ND, advanced national technical } \\
\text { certificate ANTC, advanced national business } \\
\text { certificate ANBC. }\end{array}$ \\
\hline NVQF 5 & $\begin{array}{c}\text { Technical and junior management: higher } \\
\text { national diploma and degrees }\end{array}$ \\
\hline NVQF 6 & $\begin{array}{c}\text { Professional engineers and senior management: } \\
\text { masters or doctorate in technology. }\end{array}$ \\
\hline
\end{tabular}

In Malaysia, they operate under a single QA system known as the Malaysian Qualification Agency MQA as a statutory body under the Malaysian qualification Act 2007. [27] MQA is defined as a national accreditation body that implemented the national framework called the Malaysian Qualification Framework, MQF, which develops and classifies qualifications based on the criteria approved nationally for international good practices. The Code of Practice for TVET Programs Accreditation COPTPA oversees all the facets of the TVET QA systems [28] [27]. COPTPA was developed in collaboration with MQA, the Ministry of Education, and the Department of Skills Development DSD for accreditation of the TVET sectors. The Malaysian skills certificates in TVET programs under DSD are work-based and the skills certification system is obtained through training and assessment. The students obtain the skills if they have the requirements of the National Occupational Skills Standard NOSS and they consist of five-level awards as shown in table 2 below [27].

Table 2. Award Levels of Technological Skills

\begin{tabular}{|c|c|}
\hline Award level & Technological skills \\
\hline Level 1 & Malaysian skills certificate 1 SKM 1 \\
\hline Level 2 & Malaysian skills certificate 2 SKM 2 \\
\hline Level 3 & Malaysian skills certificate 3 SKM 3 \\
\hline Level 4 & Malaysian skills diploma \\
\hline Level 5 & Malaysian skills advanced diploma BLKM \\
\hline
\end{tabular}

However, the criteria and standards of the certificates enable the holders to progress from semi-skilled to managerial functions $[29 ; 27]$. In the UK, the implementation of the European Quality Assurance Reference Framework for Vocational Education and Training EQAVET served as a network to support the 
development of QA to ensure the quality of VET for young people [30]. From the developed EQAVET framework [30], the UK has adopted the Sector Skills Councils $\mathrm{SSC}_{\mathrm{S}}$ and Sector Skills Bodies $\mathrm{SSB}_{\mathrm{S}}$ for skills development. The two councils are independent organisations that develop high-quality skill standards to support productivity in labour market demands. The SSC $S$ and $\mathrm{SSB}_{\mathrm{S}}$ advise employers on the qualifications that are best and verify evidence to ensure that valid certificates are awarded [31]. However, QA frameworks in TVET are very important for guaranteeing transparency and efficiency as well as a backbone to increase socio-economic development. QA frameworks create awareness in TVET educational systems of the importance of quality education. This is because the framework monitors the quality standards within its parameters to move towards a pro-quality culture to ensure the quality of the training outcomes. [32] and [33], affirmed that quality assurance frameworks ensure the objectives of TVET as well as the standards required for countries' national education. In a nutshell, quality assurance focuses on improving the quality of teaching-learning activities and accountability to stakeholders and the general public to improve quality standards [34]. Therefore, this study compares the quality assurance frameworks of Nigeria, Malaysia and the United Kingdom to increase the confidence of TVET stakeholders towards quality standards in terms of skills, knowledge and competencies for national building [35].

\subsection{TVET System in Nigeria}

TVET is the study of technologies and related sciences and the acquisition of knowledge, skills and attitudes in line with occupations in many sectors of economic and social life. TVET is meant to impart practical skills and knowledge for sustainable livelihoods, personal empowerment and socio-economic development [26]. The value of training is measured by the graduates' level of competency in their occupations or trades [18].In Nigeria, TVET institutions are comprised of technical colleges and Vocational Enterprise Institutions $\mathrm{VEI}_{\mathrm{S}}$ that are operationalized under the National Vocational Qualification Framework NVQF, regulated by the National Board for Technical Education NBTE [26; 36]. The framework specifies the comparability of different qualifications and how learners can progress from one stage to another. TVET at technical colleges produces craftsmen at the level of National Technical Certificate NTC, National Business Certificate NBC, Advanced National Technical Certificate ANTC, and Advanced National Business Certificate ANBC for supervisory positions in industry and teaching. TVET at $\mathrm{VEI}_{\mathrm{s}}$ enables learners to reflect creatively and transform knowledge through technological processes into a bigger economic base [26]. Training is a skill for students in post-basic education and senior secondary school who want to become craftsmen with skills or experts in a chosen trade or occupation. Therefore, Vocational Enterprise Institutions VEIs train craftsmanship in the areas of welding, sheet metal work, motor vehicle repairs, auto mechanics, panel beating, auto electrical, vulcanizing, electrical wiring (domestic and industrial), construction (plumbing, painting, bricklaying), hairdressing and beauty, fashion design, agriculture, arts (drama, dance, film production and media) [26; 37; 38]. TVET programs are also offered as national diplomas, national innovation diplomas, and advanced national technical and advanced national business certificates. Graduates, on the other hand, can progress to TVE programs to obtain a national diploma and professional certificates at the tertiary level, as well as master's and doctoral degree programs [9]. The agencies determine the national qualifications in terms of training to meet labour market demands in industrial, commercial and other related fields. The National Skills Qualification NSQ recognizes non-formal and formal learning in which recipients are trained to acquire skills, knowledge, and competencies. The graduates of the non-formal TVET programs have certification skills under the National Mass Education Commission NMEC to enable them to have competency in the world of work [9].

\subsection{TVET System in Malaysia}

Technical vocational education and training TVET in Malaysia has policies guiding them from certificate to Doctoral degree level [39]. In Malaysia, both public and private institutions offer TVET programs ranging from basic skills training to those requiring high cognitive and psychomotor awareness [39]. The TVET system in Malaysia is based on National Occupational Skills Standards NOSS which certified Malaysian skills certification. NOSS is defined as a specification of competencies expected by skilled workers who are gainfully employed [40]. The concepts and structure of the Malaysian skills certification system in the provision of TVET are largely concentrated on the lower level skills qualifications, where more than 70 per cent of graduates have Malaysian skills certificates, level 1 and 2. The majority of higher-level skill qualifications at levels 4 and 5 are delivered by government-supported public institutions. Qualification levels in TVET systems, on the other hand, include certificates, diplomas, bachelors, masters, and doctoral degrees. Therefore, for the realisation of the qualification, there are three educational areas in which qualifications are awarded under the Malaysian Qualification Framework, MQF. These are skill areas that involve training in the technical and industrial base, and the training centres are the ministry of human resources. Second, technical vocational and professional education emphasizes competencies in various occupations and is provided by polytechnics and 
community colleges under the ministry of higher education, while academic and professional education involves the acquisition of knowledge, skills, and attitudes that allow recipients to compete confidently in the world of work. Therefore, the establishment of MQF reforms was to have two sectors, academic and TVET, under a single framework for all the qualifications in Malaysia [40]. However, the revision of the TVET curriculum design and delivery depends on the practical skills acquired by the graduates who will contribute adequately towards meeting the country's socio-economic development.

\subsection{TVET System in the UK}

The TVET system in the UK has a long history that extends back to the $12^{\text {th }}$ century. The TVET system in the UK has workforce training and support to achieve the high-level skills required for the global economy. The UK TVET system provides high-quality, demand-driven technical and vocational skills to deliver professional skills. It is a dual system, with an integrated education framework from levels 1 to 8 that includes both academic and vocational education and training [41].With the evolution of qualifications and the labor market, public authorities structured the TVET sector as a national vocational qualification, the NVQ, establishing a modular system for validating competencies. And it also awards working skills to young people who move from one qualification to another by competent associations governing the various trades and crafts. There are eight levels of NVQS defined by TVET competencies as follows; [42; 43].

i. Level 1-includes the application of knowledge and skills in the implementation of a repetitive and predictable work task. The UK's professional skills in the TVET system is demand-driven, it is industry focussed and student-centered using a dynamic model of employer engagement.

ii. Level 2 - the application of knowledge and skills is the major work activities to be carried out in various frameworks and some of the activities are dynamic or non-routine that require individual roles in collaborations. As such, it is flexible because it allows both employers and training providers to develop a bespoke model of collaboration to deliver high impact to the students.

iii. Level 3-involves the application of knowledge and skills in a wide range of work activities carried out in a variety of contexts where most of which are complex and non-routine. The UK has the most diverse single national qualifications framework in the world that have 1 to 8 levels containing 26,450 national qualifications. The UK has 155 awarding organization and over 6,500 private and employer training providers that cater for 3.4 million TVET system under an integrated model that allows students and workers to move faultlessly between the vocational and academic pillars.

iv. Level 4-comprises of the application of knowledge and skills in dynamic, technical, or professional work activities conducted in a variety of contexts with a considerable degree of personal responsibility. Students and workers can achieve vocational qualifications at levels 1 to 8 including bachelor and master's degrees in their workplace.

v. Level 5- includes the application of skills and significant fundamental principles and dynamic techniques across an unpredictable variety of contexts with considerable personal accountabilities for analysis and diagnosis, design, preparation, execution and assessment. Apprenticeships allow students to develop advanced level skills without ever having to go to university- all delivered in the workplace.

vi. Level 6- modern scheme of workplace levy is made to ensure long-term financial sustainability of the apprenticeship model and enables investment in skills for greater effects.

vii. The UK TVET system framework actively evaluating its industrial needs both home and around the world to ensure continuity in the TVET system.

The UK has the toughest TVET system of quality control in the world at single quality assurance with the legislative right to remove low-quality training providers.

However, the UK TVET system has an appropriate solution for a particular situation, contextualised to best fit and provides the most productive and scalable model for occupational standards through curriculum development and teacher capacity building for training delivery. This is because the approach is a cyclical one and the model is replicable and scalable across all industries [43].

\section{Research Question}

Thus, three research questions were formulated to guide this study. These are:

i. What are the current practices of TVET quality assurance frameworks in Nigeria, Malaysia and the UK?

ii. What are the similarities and differences between the three quality assurance frameworks?

iii. How can the current TVET quality assurance frameworks be improved for technological development?

\section{Materials and Method}

The study adopted a method of qualitative document 
analysis to evaluate both printed and electronic documents [44]. The comparative study was used to gather information on quality assurance frameworks in Nigeria, Malaysia, and the United Kingdom, with a focus on TVET systems. The selection criteria of the study nations: Nigeria, Malaysia, and the United Kingdom, were based on their approaches and locations: Nigeria and Malaysia are government-led approaches with very different QAF in TEVT systems from their historical development, whereas the UK operates under a unitary approach. The countries under consideration are spread across three continents: Africa, Asia, and Europe. However, they have different governance and education and training systems in different contexts. As such, $\mathrm{QAF}_{\mathrm{S}}$ in the TVET of the studied nations give an insight into the national characteristics and context in terms of the applicability of innovations. However, the comparative study provides different policy and governance systems that allow an understanding of the particular characteristics of different nations' policy and administrative systems. It also shows how they were developed to meet needs and manage them in different national contexts. Therefore, a comparison of the TVET quality assurance frameworks aims at being a platform for information sharing on quality TVET good practices and quality improvement between the quality assurance agencies. As a result, that serves as the foundation for the comparison. According to [45], Bereday's comparative study developed for systematic comparison of educational systems includes four steps of comparative analysis. Thus, are:

i. Description of TVET quality assurance frameworks system and practices, it is connected to the systematic information on TVET QAF in Nigeria, Malaysia and the United Kingdom.

ii. Interpretation to explain the TVET quality assurance framework in terms of historical, economic and social facets of the TVET QA framework in Nigeria, Malaysia and the United Kingdom.

iii. The juxtaposition to establish similarities and differences of quality assurance framework in Nigeria, Malaysia and the United Kingdom.

iv. Then comparison involves simultaneous comparison of the TVET QA framework in Nigeria, Malaysia and the United Kingdom.

From Bereday's comparative method stated by [45], the description of Nigeria, Malaysia and the United Kingdom UK TVET quality assurance frameworks were based on the educational reports, governmental TVET reports, policy documents and journal article papers. First and foremost, the search strategies of articles were the review of quality assurance frameworks in TVET systems. As a result, three journal databases were used: Scopus, the Web of Science, and JSTOR. The search techniques were done using keywords, TVET set principles, quality assurance framework guidelines and standards for consistent application of quality assurance in TVET. Furthermore, the 'TVET quality assurance framework reports' were compiled using secondary data from the scientific literature. The reports were an explorative but selectively systematic overview of the reviewed countries by scrutinising the TVET quality assurance frameworks. Therefore, the existing literature of TVET quality assurance frameworks in the selected countries was the basis for the comparison of Nigeria, Malaysia and the United Kingdom.

\section{Result}

In this chapter, we looked into the current QAF being practiced in Nigeria, Malaysia and the United Kingdom and identified the current QAF in TVET systems (RQ1). The papers selected for the study introduce kinds of QAF in various counties under this study to enhance cooperation amongst stakeholders to ensure quality in TVET systems. QAF, in general, is quality management that demonstrates accountability to assure that quality standard components are consistent, efficient, transparent, and reliable to meet the quality TVET qualifications required by the workforce in the labor markets for socio-economic development. The agencies and bodies that ensure quality assurance for TVET under this study are shown below in table 3 .

Table 3. National Quality Assurance Agencies

\begin{tabular}{|c|c|c|}
\hline Country & $\begin{array}{c}\text { Agencies or } \\
\text { Bodies }\end{array}$ & References \\
\hline Nigeria & $\begin{array}{c}\text { NBTE, NCCE } \\
\text { and NUC }\end{array}$ & $\begin{array}{c}\text { NBTE, 2015; } \\
\text { UNESCO-UNEVOC, 2019a; } \\
\text { Akanbi, 2017 }\end{array}$ \\
\hline Malaysia & MQA & $\begin{array}{c}\text { MQA, 2019; Mazlan et al., } \\
\text { 2017 }\end{array}$ \\
\hline $\begin{array}{c}\text { United } \\
\text { Kingdom }\end{array}$ & $\begin{array}{c}\text { QAA and SSC; } \\
\text { SSB }\end{array}$ & $\begin{array}{c}\text { Teelken, 2018; Gatt, 2016; } \\
\text { Misko, 2015 }\end{array}$ \\
\hline
\end{tabular}

On the other hand, QAF is based on the continuous improvement cycle of planning, implementation and evaluation, and reviewing, as the case may be, to ensure that the qualifications obtained by the learners meet the agreed standards.

In chapter two, we indicated QAF similarities and differences (RQ2). The QAF on a global scale reflects a set of principles, guidelines, tools, and standards for continuous quality improvement activities. The framework varies across countries in terms of governance, purpose and structure.

In chapter three, we looked into how QAF can be improved in compliance with planning, management and review (RQ3).

\section{Discussion}




\subsection{What are the Current Practices of TVET Quality Assurance Frameworks?}

\subsubsection{TVET Quality Assurance Framework in Nigeria}

The role of the quality assurance framework in TVET is recognised for economic growth and providing skills for self-efficiency. This is why the government established the National Board for Technical Education NBTE to collaborate with other agencies such as the National Universities Commission NUC and National Commission for Colleges of Education NCCE, and other relevant stakeholders to determine human resources needed with a view to developing responsive TVET that will meet the skills needed [21]. Nigeria operates under multiple quality assurance agencies, namely the National Universities Commission NUC, National Commission for Colleges of Education NCCE and National Board for Technical Education NBTE. This is to ensure quality in all the sectors of her educational system. However, the NBTE was recognised to improve the quality of TVET delivery to achieve the appropriately skilled workforce needed for the country's industries, commerce and agriculture and socio-economic development. Based on the above, the Federal Executive Council FEC on April 10, 2013, approved the National Skills Qualifications Framework NSQF where the national vocational qualification framework NVQF structure was recognised within the national educational system [9]. NSQF learning outcomes are related to NUC and NCCE learners in making qualification decisions at each level of TVET, to enable learners to aspire to the Nigerian vision of 20-2020 in the world economy. However, the effort has ambiguous goals due to corruption, insufficient power supply, insufficient funding of the TVET sector, and insecurity [36]. This has hampered the attraction of international investors to invest in industrial areas as it will improve Nigeria's hi-tech industry. With the number of universities, polytechnics and mono-technics, colleges of education and technical and vocational enterprise institutions in Nigeria, the TVET educational system has been disconnected from industrial and socio-economic needs by neglecting competence and emphasizing paper qualifications [36; 37]. However, the assessment and evaluation processes in TVET systems remain academic rather than industry-based standards to promote a skilled workforce for socio-economic development.

\subsubsection{TVET Quality Assurance Framework in Malaysia}

Quality assurance framework is a structure and management system that demonstrates a high level of accountability and it has a mission in carrying out quality functions supported by plans and action [27]. The system standards are consistent, efficient, transparent and reliable [46; 27]. The TVET framework ensures that the cluster learning outcomes are described in terms of
i. $\quad$ Knowledge and understanding
ii. Thinking skills

iii. Useful work skills that focus on; practical skills, communication skills, management skills, reliability and autonomy.

iv. Individual and entrepreneurial skills, and

v. Moral values and professionalism.

However, the Malaysian Qualification Agency MQA, established under the Act in 2007, created the Malaysian Qualification Framework MQF, setting requirements for qualifications in higher education and training institutions. The MQF refers to a qualification in Malaysia that defines the levels of learning, learning outcomes and qualification title for each level applied to certification in the academic and TVET systems [40]. Furthermore, the single quality assurance agency MQA introduced the review of MQF in TVET, where the skills sector and technical and vocational sector were merged into TVET sectors. Therefore, the Code of Practice for TVET Programs Accreditation COPTPA operates as a single QA system for the TVET programs. This COPTPA was established with the collaboration of MQA, Department of Skills Development DSD, ministry of education, ministry of human resources in consideration of the requirements of TVET programs by the Malaysian QA areas of quality standards such as:

i. Program delivery and development

ii. Students' learning assessment

iii. Educational resources

iv. Management of the programs

v. Teaching staff

vi. Students selection and support services, and

vii. Monitoring, review and continual quality improvement of the programs.

However, the quality assurance guidelines were implemented by the higher education institutions and training providers as standards for offering TVET programs in Malaysia. The standards certified by the MQA and DSD are used as a benchmark in determining the TVET graduates' performances in their areas of the discipline.

\subsubsection{TVET Quality Assurance Framework in the UK}

The United Kingdom's UK quality assurance framework in TVET maintained its quality of education through the Higher Education Quality Council (HEQC) and the Internal Network for Quality Assurance Agencies in Higher Education (INQAAHE) to ensure quality assurance in teaching and learning [47]. Independent bodies, the Quality Assurance Agency in higher education QAA and Sector Skills Councils SSC $_{\mathrm{s}}$, and Sector Skills Bodies $\mathrm{SSB}_{\mathrm{S}}$ are funded by subscriptions from universities and colleges of higher education also a vital role in VET teaching assessment. The SSCs and SSBs conduct VET institutional audits to safeguard, monitor, and report standards among them over time, which prompted scrutiny of the institutions' internal quality 
assurance system for an emphasis on VET students and learning, [47; 30; 31]. In the UK, the Department for Children, Schools and Families, DCSF, was created in June 2007. DCSP is the main governmental body for the quality assurance of the VET system. In October 2008, the center for excellence in leadership, CEL, and the quality improvement agency, which became the learning and skills improvement services, CSIS, were established. In 2009, the European Quality Assurance Framework for Vocational Education and Training, EQAVET, provided states with a reference framework to help them to monitor and implement quality assurance processes for continuous improvement. On the other hand, the aim was to use the framework to increase the transparency and consistency of VET policy development and to promote mutual trust in student and labor mobility and lifelong leadership.

\subsection{What are the Similarities and Differences between the Three Quality Assurance Frameworks?}

\subsubsection{Similarities and Comparative Work of Quality Assurance Framework in TVET Systems}

The TVET quality assurance framework reflects a strong commitment to evidence-based decision making and continuous quality improvement. As a result, this aligns with achieving excellence in all aspects of quality in TVET work through accountability, collaboration, and students' approaches to teaching and learning. A framework is a set of principles, guidelines, tools, and standards that act as a reference for guiding the consistent application of quality assurance activities in TVET [38]. Therefore, the TVET quality assurance framework serves as a guide for acquiring skills, knowledge and attitudes to be applied in the workplace [48]. This is to achieve high technologies that are inclusive, sustainable and innovative and a qualified workforce for socio-economic development. However, QA frameworks in TVET are designed to maintain quality standards in regulatory and legislative requirements for enhancing TVET effectiveness to achieve set objectives. Quality assurance in the UK has been introduced into policy and reform for quite a long time, compared to Malaysia and Nigeria. Malaysia and the United Kingdom, on the other hand, have made greater efforts within their educational sectors to prepare TVET systems for future challenges and to continuously improve the QA system. The following are the approaches to quality assurance systems used in the study countries: Nigeria uses a supervisory approach, Malaysia uses accreditation, while the UK uses an audit. Therefore, quality assessment is one of the major processes for ensuring the requirements of competency and standards in achieving quality TVET systems. The strategies engaged by the study nations reviewed are: strong external and internal evaluation processes are employed across Malaysia and the UK, and the process of external evaluation is a task of the QA agencies and importance is placed on the institutions implementing a strong internal evaluation process, while in Nigeria, evaluation is placed on the National Occupation Skills Standards. NOSS of the training institutions internal evaluation function and external evaluation function is centralised [38; 48]. Thus, the TVET system in Malaysia and UK is comparatively associated in their structure when compared with TVET in Nigeria. This is because the governance of the TVET systems in Malaysia and the United Kingdom has provided a high level of consistency in their QA systems. However, the frameworks vary across countries in terms of governance, purpose and structure. In the United Kingdom, the TVET system is based on a unitary approach. The TVET framework is industry-linked and provided by sector skills councils and sector skills bodies. The organisations aim to develop high-quality skills standards among trainees for employers to support productivity and profitability growth and enhance competitiveness in the UK labour markets. They are also responsible for verifying evidence to ensure that valid apprenticeship certificates are awarded [41]. In Malaysia, the TVET system is government-led, with industry-leading TVET curriculum development to improve efficiency through promotional activities. The governance harmonised accreditation between the Malaysian qualification agency, MQA, and the department of skills development, DSD. To be in line with the academic area, the code of practice for TVET programme accreditation, COPTPA, was developed in line with the code of practice for programme accreditation, COPPA. This is done to help learners achieve competencies and meet the demands of national occupational skill standards. And the standards for certification are recommended by MQA and DSD as a benchmark to determine learners' performance [27]. In terms of knowledge and skills, the standards are in line with industry expectations. In Nigeria, the TVET system operates based on a government-led approach where the recent reform in TVET institutions has resulted in the development of the Nigerian skills qualification framework, NSQF, and the flexible skills development system, FSD. These frameworks were designed to improve quality training using ICT tools, and TVET developed from simply training knowledgeable professionals. Hence, the training has inadequate ICT facilities to incorporate and make functional training systems [9]. However, the NSQF is a system for the development, classification and recognition of skills, knowledge and competencies acquired by individuals. The framework's goal is to promote lifelong learning to ensure quality by monitoring and assessing it in line with the requirements. In Malaysia and the UK, the QAF in TVET systems supports professional skills in both academic and vocational training, which makes their TVET system productive and has a scalable model for occupational standards across industries and teaching, while in Nigeria, 
the TVET system is concerned with vocational training. The purpose and structure of Malaysia and the UK's TVET quality assurance frameworks are underpinned by the principles of transparency, continuous improvement, agreed quality standards and promotion of mutual understanding to strengthen cooperation and the stakeholders' commitment. While the purpose and structure of TEVT QAF in Nigeria is overshadowed by corrupt practices to the detriment of transparency, continuous improvement and agreed quality standards. As a result, an inadequate realization of the purpose and structure across established QAFs results in a lack of framework effectiveness. The table 4 below shows the differences in the QAF of the three nations: Nigeria, Malaysia and the United Kingdom.

Table 4. Differences in the TVET National Quality Assurance Frameworks

\begin{tabular}{|c|c|c|c|}
\hline Indicators & Nigeria & Malaysia & $\begin{array}{c}\text { United } \\
\text { Kingdom } \\
\text { UK }\end{array}$ \\
\hline $\begin{array}{c}\text { QA } \\
\text { approaches }\end{array}$ & Supervisory & Accreditation & Audit \\
\hline Governance & $\begin{array}{c}\text { Government-led } \\
\text { approach }\end{array}$ & $\begin{array}{c}\text { Government-led } \\
\text { approach }\end{array}$ & $\begin{array}{c}\text { Unitary } \\
\text { approach }\end{array}$ \\
\hline Evaluation & Internal & $\begin{array}{c}\text { External and } \\
\text { internal }\end{array}$ & $\begin{array}{c}\text { External } \\
\text { and internal }\end{array}$ \\
\hline $\begin{array}{c}\text { Structure of } \\
\text { the TVET } \\
\text { system }\end{array}$ & $\begin{array}{c}\text { Vocational } \\
\text { training }\end{array}$ & $\begin{array}{c}\text { Academic and } \\
\text { vocational } \\
\text { training }\end{array}$ & $\begin{array}{c}\text { Academic } \\
\text { and } \\
\text { vocational } \\
\text { training }\end{array}$ \\
\hline
\end{tabular}

Table 5. Technologies Areas of the TVET National Quality Assurance Framework

\begin{tabular}{|c|c|c|}
\hline Country & Levels & Areas \\
\hline Nigeria & 8 & $\begin{array}{ll}\text { - } & \text { Knowledge } \\
\text { - } & \text { Skills } \\
\text { - } & \text { Application and competence } \\
\text { - } & \text { Social skills } \\
\text { - } & \text { Lifelong learning }\end{array}$ \\
\hline Malaysia & 8 & $\begin{array}{ll}\text { - } & \text { Practical skills } \\
\text { - } & \text { Knowledge } \\
& \text { Social skills, attitudes, values, } \\
\text { - } & \text { professionalism and responsibilities } \\
& \text { Problem-solving and scientific } \\
\text { skills } \\
\text { - } \quad \text { Information management } \\
\text { - } \quad \text { Lifelong learning skills } \\
\text { Entrepreneurial skills }\end{array}$ \\
\hline $\begin{array}{l}\text { United } \\
\text { Kingdom } \\
\text { (UK) }\end{array}$ & 8 & 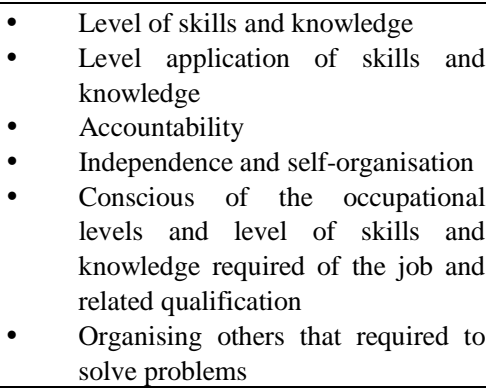 \\
\hline
\end{tabular}

However, in table 5 , is the outline of the fundamental structures of the national quality assurance frameworks [49; 50; 43 and 51]. The table 5 provides insight into the best practices of quality assurance frameworks in TVET to improve efficiency and trainee confidence. The quality assurance frameworks in TVET in Nigeria, Malaysia, and the United Kingdom have shown below the differences in the technologies area required by each country for inclusion, sustainability, creativity, and innovation. This is to have a qualified workforce in the areas needed for socio-economic development.

\subsection{How Can Current TVET Quality Assurance Frameworks be improved for Socio-Economic Development?}

The effective quality assurance framework for TVET systems is based on decisions made by policymakers, regulators and accreditation agencies about what is to be achieved [31]. Quality assurance framework standards are developed for compliance to improve the quality assurance framework that can be judged based on the three components. Thus, are:
i. integrated planning
ii. integrated review
iii. management

However, the quality assurance framework aims to set up a continuous quality improvement model that includes planning, implementing, monitoring/reviewing and improving. This is to enable the framework to achieve the intended promises, quality outcomes and meet statutory and regulatory requirements for quality assurance. The quality assurance framework reflects the quality standards following the stated principles to ensure quality in TVET systems [31].

i. Transparency and accountability- which focus on good governance to assure reporting requirements, reliability and relevance in public reporting of processes and performance.

ii. Integration and balance- refer to the involvement of the stakeholders in balancing the set quality standards to ensure improvement and innovation.

iii. Minimum standards- focus on the set of quality standards on inputs, processes and outputs.

iv. Quality assurance and improvement- TVET quality systems assure the set quality standards to promote improvement in the system.

v. Comparability- quality assurance varies from country to country and the measures have to be upon comparable quality standards and expectations of each country.

vi. Consistency and continuity- include providing consistent application of quality standards to maintain stakeholders' confidence.

vii. Good governance- this includes independence in decision makings and actions to ensure quality standards requirements. This is to develop a culture 
of ownership, participation and responsiveness where all staff understand their collective responsibility for quality processes and outcomes

Thus, most of the research on the TVET quality assurance framework according to [52], [54] and [53] has stressed quality assurance improvement through the guidance of a framework to achieve the desired technological development and to meet the market demands that will lead to socio-economic development. Table 6: below as indicated by the researchers' response on the quality assurance framework in TVET informed approaches for best practices in TVET for skills and knowledge required for labour market demands.

However, the quality assurance framework according to [52], [54] and [53] has standard components appropriate and adequate for continuous quality improvement to deliver relevant skills, knowledge and competencies. And it also provides confidence in employers of labour, and industries in terms of skills, knowledge and competency.

\subsection{QA Framework Reform in the Context of TVET}

Quality assurance framework reforms are intended to deal comprehensively with quality improvement in the country's TVET systems. Reforming TVET is to play a major role in the development of policies, principles, strategies in the area of TVET educational supply, development of teaching and learning process, examinations and certification, and quality assurance. Furthermore, reforming the QA framework in TVET is to ensure quality education that will change learning practice towards equipping people with practically oriented work that emphasises learning by doing, working in a team and thinking creatively coupled with efficient evaluation to enable skills development that will be valued by employers. Therefore, it is believed that the QA framework in the TVET system in each country differs, but it is pertinent to identify ways for an effective and quality TVET system to regulate the core skills challenges in the national learning environment in terms of relevance to the labour market, private sector involvement and good access for learners through continuous financing of the TVET systems for core work skills. However, when the issue of improving the QA framework is raised, policymakers in Africa, particularly Nigeria, who identify an impediment to achieving TVET goals are not of common interest. This is because of the corrupt practices in the governance of African nations, particularly Nigeria. The engagement of TVET stakeholders must focus on the goals of technological development to ensure that TVET curricula and qualifications are in line with TVET objectives for socio-economic development. From the studies on TVET educational reforms in European, American and Asian countries, it is justified that successful TVET QA frameworks of a country are based on developing quality standards for knowledge, skills and competence of the graduates [19]. This could be achieved through upgrading occupational standards and educational standards, modern demand-driven curricula, the competencies of the teachers, satisfying labor market demands and the skills needed for sustainability. However, in most developing countries, especially Nigeria, the quality of TVET graduates has left much to be desired because the graduates cannot create employment for themselves due to challenges in the training process. This is because the quality assurance agencies that are currently in operation are having financial difficulties in equipping the TVET system to meet the goal targets outlined in the Nigerian National Policy on Education 2014. Hence, limiting the TVET QA framework is impactful on skills, employability and its relevance to the needs of the country's national development. Therefore, the QA framework needs to be improved for the betterment of the TVET educational quality systems.

Table 6. Related Works of the TVET Quality Assurance Framework Requirements

\begin{tabular}{|c|c|c|}
\hline Author and Title & Description & Approaches \\
\hline $\begin{array}{c}\text { Said (2018). Vocational } \\
\text { teaching-learning through the eyes of } \\
\text { undergraduate vocational students in } \\
\text { Malta: a qualitative exploratory study }\end{array}$ & $\begin{array}{c}\text { Stressed on giving TVET a voice that can } \\
\text { attract students into TVET systems and be } \\
\text { effective learning in promoting both economic } \\
\text { and socio-economic growth, empowering and } \\
\text { alleviating poverty amongst societies and } \\
\text { increasing productivity. }\end{array}$ & $\begin{array}{c}\text { Applying a framework that would enable } \\
\text { marketable skills required of various } \\
\text { industries and employers of labours. }\end{array}$ \\
$\begin{array}{c}\text { Bagale (2015). Technical education and } \\
\text { vocational training for sustainable } \\
\text { development }\end{array}$ & $\begin{array}{c}\text { Provides a guide for possible evidence and } \\
\text { current and future workforce needs, promote } \\
\text { sustainable TVET programmes quality and } \\
\text { ensuring standing impact for individual } \\
\text { students and stable country economy. }\end{array}$ & $\begin{array}{c}\text { Developing and delivering learning and } \\
\text { assessment strategies and resources } \\
\text { through QA framework which include } \\
\text { stakeholders' engagement, using } \\
\text { technology, quality staff, benchmarking, } \\
\text { products and innovation practices. }\end{array}$ \\
$\begin{array}{c}\text { Chen \& Bonner (2019), A framework for } \\
\text { classroom assessment, learning, and } \\
\text { self-regulation }\end{array}$ & $\begin{array}{c}\text { The framework act to guide the end products to } \\
\text { meet the objectives and fulfil the outcomes of } \\
\text { learning. }\end{array}$ & $\begin{array}{c}\text { It includes all the activities that are } \\
\text { necessary to achieve the desired learning } \\
\text { outcomes. This covers all the } \\
\text { responsibilities of the teachers in delivering } \\
\text { the expected outcomes. }\end{array}$ \\
\hline
\end{tabular}




\section{Conclusions and Suggestion}

Quality in TVET educational systems cannot be overlooked by any government because nations achieve their desire to become industrialized nation through the good practices of the TVET QA framework. More so, the TVET QA frameworks focus on meeting the countries' TVET education quality standards and continually improving the TVET system for better outcomes. The purpose of comparing TVET QA frameworks is to identify a quality assurance challenge that is critical to assuring quality in TVET training and educational standards. Though this study compared the QA frameworks of three countries, it was observed that Nigeria has multiple QA frameworks that lack developmental and continuous improvement culture, procedures for the providers and teachers improvement. And also, it lacks a structured funding model to equip the TVET educational system, compared to the UK and Malaysian TVET QA frameworks. However, the current TVET QA framework practices, the similarities and differences, and ways to improve the frameworks to enhance socio-economic development were discussed in this study. The comparison of the QA framework systems of the three countries demonstrated in this study differs in structure and procedure, with Nigeria and Malaysia using a government-led approach and the UK using a unitary approach. But the frameworks are similar in their operations for quality improvement and sustainability for the nation's socio-economic development. It is also comparable to countries needing educational systems that meet international standards. However, the Nigerian government needs to encourage and promote its QA framework in the TVET system by equipping the system. Encourage society to change young people's negative perceptions of TVET and to encourage young people to develop an interest in TVET. The most important thing is the government's commitment to prioritizing student enrolment to develop the TVET educational system as a first-choice education, rather than viewing the TVET educational system as a second-choice education.

\section{Acknowledgements}

We would like to acknowledge the Tertiary Education Trust Fund Nigeria, TET Fund, for the funding of this research. In addition, we appreciate the universal journal of educational research management for the high quality of its papers, which promote educational research all over the world.

\section{REFERENCES}

[1] Seyfried, M.\& Pohlenz, P. “Assessing quality assurance in higher education: quality managers' perceptions of effectiveness,” Eur. J. High. Educ., vol. 8, no. 3, pp. 258271, 2018.

[2] Taylor, M. J., Mcnicholas, C., Nicolay, C., Darzi, A. Bell, D. \& Reed, J. E. "Systematic review of the application of the plan - do - study - act method to improve quality in healthcare,” pp. 290-298, 2014.

[3] Ansah, H. P., Swanzy, F. \& Nudzor, P. "Balancing the Focus of Quality Assurance Frameworks of Higher Education Institutions in Africa: A Ghanaian Con,” Intech, vol. I, no. tourism, p. 13, 2017.

[4] Sokwane, L. \& Adekanmbi, G. "Exploring the Teaching and Learning Quality Question in Technical Education in Botswana,” Int. J. Adult Vocat. Educ. Technol., vol. 10, no. 2, pp. 25-39, 2019.

[5] Zhang, L. Y., LIU, S., YUAN, X. \& LI, L. "Standards and Guidelines for Quality Assurance in the European Higher Education Area: Development and Inspiration," in DEStech Transactions on Social Science, Education and Human Science, 2019.

[6] Tsabedze, V. \& Ngoepe, M. “A framework for quality assurance for archives and records management education in an open distance e-learning environment in Eswatini," Int. Journal of Inf. Learn. Technol., vol. 38, no. 1, pp. 91-102, 2021.

[7] Amadi, E. K. \& Johnwest, N. S. "Current Trends in Financing Vocational Education in Nigeria,” Int. J. Educ. Eval., vol. Vol.2 No., no. May, pp. 12-18, 2016.

[8] International Labour Office, A Skilled Workforce for Strong, Sustainable and Balanced Growth, no. November. 2010.

[9] UNESCO-UNEVOC, UNESCO-UNEVOC TVET Country Profiles Nigeria, no. 8938108084. 2019.

[10] Abugre, J. B. "Institutional governance and management systems in Sub-Saharan Africa higher education: developments and challenges in a Ghanaian Research University,” High Educ., pp. 323-339, 2018.

[11] Hrmo, R., Miština, J. \& Krištofiaková, L. “Improving the Quality of Technical and Vocational Education in Slovakia for European Labour Market Needs,” Int. J. Eng. Pedagog., vol. 6, no. 2, p. 14, 2016.

[12] Shefiu, R. \& Ayika, S. N. "Technical Vocational Education and Training (TVET) as A Panacea to Solving Nigeria's Youths' Problem of Unemployment," Cont. J. Soc. Sci. Raheem Ayika, vol. 1, no. 1, pp. 1-16, 2019.

[13] Green, F. \& Henseke, G. "The changing graduate labour market : analysis using a new indicator of graduate jobs," IZA J. Labor Policy, 2016.

[14] International Labour Organization, "Guidelines for Model TVET Institutions (MTIs),” no. May 2019.

[15] Kromydas, T. "Rethinking higher education and its relationship with social inequalities: Past knowledge, present state and future potential," Palgrave Commun., vol. 3, no. 1, pp. 1-11, 2017.

[16] Asiamah, E. F., Mensah, N. \& Oteng-Abaye, H. K. "General, Target, and Accessible Population : Demystifying the Concepts for Effective Sampling,” Qual. 
Rep., vol. 22(6), pp. 1607-1621, 2017.

[17] UNESCO, “Discussion on SDG 4 - Quality education,” no. July 2019.

[18] Okoye, R. \& Arimonu, M. O. "Technical and vocational education in Nigeria : issues, challenges and a way forward," J. Educ. Pract., vol. 7, no. 3, pp. 113-118, 2016.

[19] Caves, S. \& Baumann, K "Getting there from here: A literature review of VET reform implementation,” ETH Zurich KOF Swiss Econ. Institute, 2018.

[20] Fadokun James Banji, "External Quality Assurance in Higher Education: The Need for a paradigm shift,” $B r . J$. Psychiatry, vol. 112, no. 483, pp. 211-212, 2017.

[21] National Board for Technical Education (NBTE), “National Board for Technical Education (NBTE) Kaduna Digest of Statistics of Technical Vocational Education and Training (TVET) Institutions in Nigeria: 2014/2015,” vol. 5, 2015.

[22] OECD, “Assessment of higher education learning outcomes,” vol. 1, 2012.

[23] Pongo, N. A. \& Obinnim, E. “Changing Landscape of Industry Practice: The Role of Quality Technical Vocational Education and Training in Ghana,” Issn, vol. 33, no. Psd Ii, pp. 2224-6061, 2015.

[24] National Commission for Colleges of Education, "Nigeria Certificate in Education Minimum Standards for the Federal Republic of Nigeria,” no. National Commission for Colleges of Education plot 829 Cadastral Zone AOI Ralph Shodeinde Street Garki Abuja, p. 13, 2012.

[25] National Commission for Universities, "NATIONAL UNIVERSITIES COMMISSION For UNDERGRADUATE PROGRAMMES In PHARMACY,”. November 2015.

[26] The Federal Republic of Nigeria, “NATIONAL-POLICY-ON-EDUCATION.” 2014.

[27] MQA, "Code of Practice for TVET Programme Accreditation,” 2019.

[28] R. B. Mason, S. N. Mbambo, and M. A. Pillay, "Service quality at technical and vocational education and training colleges: Perception according to demographic factors," $J$. Tech. Educ. Train., vol. 10, no. 1, pp. 15-29, 2018.

[29] Rashidah Mokhtar, M.A, Azizah Abdul Rahman, \& Siti Hajar Othman. "Malaysian Academic Quality Assurance System in the context of issues, challenges and best practices," in Knowledge Management International Conference (KMICe), pp. 1-7, 2014.

[30] Gatt, S. "Implementing the European Quality Assurance in Vocational Education and Training ( EQAVET) at National Level : Some Insights from the PEN Leonardo Project 1,” vol. 3, no. 1, pp. 29-45, 2016.

[31] Misko, J. "Regulating and quality-assuring VET: international developments,” 2015.

[32] Adrian C., Ligia D. \& Remus P. European Higher Education Area: The Impact of Past and Future Policies. 2018.

[33] Machumu, H. J. \& Kisanga, S. H. “Quality Assurance
Practices in Higher Education Institutions: Lesson from Africa,” J. Educ. Pract., vol. 5, no. 16, pp. 144-157, 2014.

[34] Geven, K. \& Maricut, A. "Forms in search of substance: Quality and evaluation in Romanian universities," Eur. Educ. Res. J., 2015.

[35] Evans, C., Howson, C. K. \& Forsythe, A. "Making sense of learning gain in higher education,” High. Educ. Pedagog., vol. 3, no. 1, pp. 1-45, 2018.

[36] Akanbi, G. O. "Prospects for technical and vocational education and training (TVET) in Nigeria: Bridging the gap between policy document and implementation," Int. Educ. J., vol. 16, no. 2, pp. 1-15, 2017.

[37] UNESCO-UNEVOC, "Promoting Innovation in TVET," no. 34, 2019.

[38] Unesco and Commonwealth of Learning, and Blended Using ICTs and Blended Using ICTs Transforming Learning in and Blended Using ICTs Transforming Learning in Transforming Learning in TVET Transforming Learning in TVET. 2017.

[39] Norhafiza, R. et al., "Malaysian TVET lecturer and Industrial Training through National Occupational Standard Skills,” Humanit. Soc. Sci. Rev., vol. 7, no. 2, pp. 212-219, 2019.

[40] MQA, "Malaysian Qualifications Framework ( MQF ) 2 nd Edition," 2018.

[41] British Council, “The UK skills system,” 2016.

[42] International Labour Organization, Integrating core work skills into TVET systems: Six country case studies. International Labour Office, 2015.

[43] Department for International Trade, "UK Technical and Vocational Skills System,” 2018.

[44] Gross, J. M. S. The SAGE Encyclopedia of Educational Research, Measurement, and Evaluation. Thousand Oaks: SAGE Publications, Inc, 2019.

[45] Adick, C. "Bereday and Hilker: origins of the 'four steps of comparison’ model,” Comp. Educ., vol. 54, no. 1, pp. 35-48, 2018.

[46] Mazlan, A. S., Manaf, Z. A. \& Talib, Z. A. Technical Vocational Education \& Training ( TVET ) in Malaysia: Selected Works. 2017.

[47] Teelken, C. “Teaching assessment and perceived quality of teaching: a longitudinal study among academics in three European countries,” Eur. J. High. Educ., vol. 8, no. 4, pp. 382-399, 2018.

[48] Unesco-unevoc, "A synthesis of best practices in TVET quality assurance in selected South Asian countries,” 2017.

[49] Deba, A. A "Conceptual Framework of Service-Learning in Technical and,” no. July, p. 318, 2015.

[50] Mittal, R.K., Garg, N. \& Yadav, S. K.“Quality assessment framework for educational institutions in technical education: a literature survey," Horiz., vol. 26, no. 3, pp. 270-280, 2018.

[51] Bateman, A. \& Coles, M. Towards Quality Assurance of 
Technical and Vocational Education and Training. 2017.

[52] Said, A. "Vocational teaching-learning through the eyes of undergraduate vocational students in Malta: A qualitative exploratory study," Int. J. Res. Vocat. Educ. Train., vol. 5, no. 1, pp. 42-63, 2018.
[53] Bagale, S. "Technical Education and Vocational Training for Sustainable Development,” vol. 1, no. 1, 2015.

[54] Chen, P. P. \& Bonner, S. M. “A framework for classroom assessment, learning, and self-regulation,” Assess. Educ. Princ. Policy Pract., vol. 00, no. 00, pp. 1-21, 2019. 